\title{
PENGOLAHAN SAMPAH PETERNAKAN DAN PERTANIAN DENGAN METODE PENGOMPOSAN
}

\author{
Iasha Diana Putri \\ Jurusan Teknik Lingkungan, Fakultas Arsitektur Lanskap dan Teknologi Lingkungan, \\ Universitas Trisakti, Jakarta, Indonesia \\ Email korespondensi: Iasha08215029@std.trisakti.ac.id
}

\begin{abstract}
ABSTRAK
Meningkatnya pertumbuhan penduduk akan meningkatkan jumlah sampah di Indonesia. Pengolahan sampah di Indonesia masih banyak menggunakan metode 3P (Pengumpulan, Pengangkutan dan Pembuangan) tetapi tidak semua sampah dapat menggunakan metode tersebut, contohnya sampah peternakan dan pertanian. Sampah peternakan yang sering digunakan adalah kotoran dan urin sapi, sampah pertanian adalah sisa hasil panen. Sampah peternakan kandungan nutrisi nitrogen, fosfor dan kalium yang baik bagi tanah sedangkan sampah pertanian memiliki kandungan nutrisi yang baik untuk mikroba. Sampah peternakan dan pertanian yang biasanya hanya dibiarkan dapat diubah menjadi suatu produk yang bernilai dan dapat digunakan kembali dengan metode pengomposan. Tujuan dari karya ilmiah ini adalah untuk mempelajari pengolahan sampah peternakan dan pertanian dengan metode pengomposan. Pengomposan adalah salah satu proses dekomposisi biologi berbiaya rendah. Proses pengomposan digerakkan oleh aktivitas mikroba. Metode pengomposan dianggap paling efisien dan ramah lingkungan, karena kompos dapat digunakan sebagai kondisioner tanah yang mengandung nutrisi tinggi untuk tanah. Kompos juga dapat meningkatkan kesuburan tanah, struktur tanah, kapasitas menahan air, sifat fisika dan kimia, $\mathrm{pH}$ tanah, aktivitas mikroba dan juga produksi tanaman.
\end{abstract}

Kata Kunci: Pengomposan; Kotoran Sapi; Sampah Pertanian

\section{PENDAHULUAN}

Tingginya angka kelahiran dan pertumbuhan penduduk akan mengakibatkan meningkatnya jumlah sampah yang ada di Indonesia. Sampah yang dihasilkan bervariasi, sampah perkotaan akan berbeda dengan sampah desa. Sampah perkotaan meliputi sampah organik, anorganik dan sampah B3. Sedangkan sampah desa biasanya hanya sampah organik seperti sampah rumah tangga, sampah sampah peternakan dan pertanian.

Pengolahan sampah di Indonesia masih banyak menggunakan metode yang sederhana, bahkan masih banyak beranggapan pengolahan sampah hanya dengan program 3P (Pengumpulan, Pengangkutan dan Pembuangan) tetapi metode tersebut tidak dapat digunakan pada sampah peternakan dan pertanian. Biasanya sampah peternakan dan pertanian hanya dibiarkan begitu saja, sampah tersebut akan menjadi masalah serius, baik dari segi estetika dan segi kesehatan.

Sampah peternakan yang sering digunakan adalah kotoran sapi. Salah satu pengolahan yang banyak digunakan untuk sampah peternakan dan pertanian adalah dengan membuat produk kompos atau pupuk organik dengan cara pengomposan. Kompos yang berasal dari sampah pertanian dan peternakan memiliki kandungan nitrogen, kalium dan serat yang tinggi. Karya ilmiah ini dibuat dengan tujuan untuk mempelajari pengolahan sampah pertanian dan peternakan dengan metode pengomposan sehingga menjadi produk yang bernilai dan dapat digunakan kembali. 


\section{TINJAUAN PUSTAKA}

\section{Sampah Peternakan}

Kotoran sapi telah lama dikenal sebagai kotoran hewan dari sampah peternakan yang paling diminati karena kandungan nutrisi dan bahan organiknya yang tinggi. Penambahan kotoran sapi akan meningkatkan kandungan karbon organik tanah terdegradasi yang dapat menyebabkan peningkatan aktivitas mikroorganisme tanah yang menguntungkan dan meningkatkan ketersediaan nutrisi bagi tanaman dari tanah (Zaman et al, 2017)

Ketika diubah menjadi kompos, kotoran sapi menjadi pupuk yang kaya akan nutrisi. Kotoran sapi mengandung tiga nutrisi penting yang dibutuhkan oleh tanaman untuk pertumbuhannya yang sehat, yaitu Nitrogen, Fosfor dan Kalium. Selain kotoran sapi, urin sapi mengandung $95 \%$ air, $2,5 \%$ urea dan sisanya 2,5\% merupakan campuran garam, hormon, enzim dan mineral. Urin sapi sangat berguna untuk membunuh sejumlah bakteri, virus dan jamur yang tanah terhadap pestisida dan herbisida. Urin sapi yang dikombinasikan dengan ekstrak tumbuhan digunakan menjadi desinfektan yang ramah lingkungan (Ram, 2017).

\section{Sampah Pertanian}

Sampah sayuran mendominasi jumlah total sampah yaitu rata-rata 2 ton/hari. Komposisi sampah sayuran paling banyak ditemukan antara lain bayam, sawi putih, sawi hijau, kol, dan sebagian kecil sayuran yang lain. Sampah sayuran ini biasanya akan diangkut menuju Tempat Pembuangan Akhir (TPA), sedangkan sisanya akan tertinggal. Sampah sayuran yang tertinggal belum mendapatkan penanganan khusus dan akan menimbulkan pencemaran lingkungan (Febriyantiningrum, 2018). Sampah sayuran menyediakan nutrisi yang baik untuk mikroba, tidak mengandung patogen dan aman untuk lingkungan (Kalpana et al, 2011).

Karakteristik sampah sayuran dan kotoran sapi dapat dilihat pada Tabel 1

Tabel 1 Karakteristik Sampah Sayuran dan Kotoran Sapi

\begin{tabular}{lll}
\hline Parameter & Sampah Sayuran & Kotoran Sapi \\
\hline $\mathrm{C}$-Organik (\%) & 38,23 & 43,17 \\
\hline $\mathrm{N}-$ Total (\%) & 2,25 & 1,12 \\
\hline $\mathrm{P}_{2} \mathrm{O}_{5}$ & 1,15 & 2,10 \\
\hline $\mathrm{K}_{2} \mathrm{O}$ & 2,43 & 2,27 \\
\hline $\mathrm{C} / \mathrm{N}$ Rasio & 7,30 & 51,30 \\
\hline $\mathrm{pH}$ & 7 & 7,3 \\
\hline Kadar Air (\%) & 53,85 & 38,55 \\
\hline
\end{tabular}

(Sumber: Studi Potensi Limbah Sayuran Pasar Baru Tuban Sebagai Pupuk Cair Organik, 2018)

\section{Pengomposan}

Komposisi sampah perkotaan berdasarkan hasil sampling, sampah organik sebanyak $76 \%$ sedangkan sampah non organik $24 \%$. Sampah organik berasal dari kegiatan rumah tangga seperti sampah dapur dan sampah halaman. Jenis sampah non organik yang ditemukan berupa sampah plastik, kertas, logam, gelas, kain dan sampah lain-lain (Revani et al, 2016). Sampah padat rumah tangga memiliki efek langsung dan tidak langsung pada lingkungan dan kesejahteraan manusia. Efek langsung pada kesehatan manusia, sehingga menciptakan dampak sosial ekonomi yang signifikan. Efek tidak langsung, yang mempengaruhi sosial ekonomi dan keberlanjutan suatu tempat (Hakami and El-Sayed, 2015).

Sistem pengolahan sampah kota yang sedang dilakukan sebagian besar baik kategori kota kecil, kota sedang, kota besar maupun kota metropolitan di Indonesia hanyalah pengumpulan, pengangutan dan pembuangan disebut 3P. Sampah tersebut hanya 
dikumpulkan dari sumber dan diangkut menuju TPS dan akhirnya dibuang ke Tempat Pembuangan Akhir. Masih banyak yang beranggapan mengolah sampah hanya dengan 3R (Reduce, Reuse, Recycle), ada juga dengan pembakaran atau TPA dengan Sanitary Landfill saja (Suprapto, 2010).

Pengomposan adalah salah satu proses dekomposisi biologi berbiaya rendah. Proses pengomposan digerakkan oleh aktivitas mikroba. Parameter-parameter fisik kimia meliputi suhu, kadar air, rasio $\mathrm{C}: \mathrm{N}$ dan $\mathrm{pH}$. Pengomposan adalah alternatif sistem pengolahan limbah padat, dapat digunakan untuk mendaur ulang bahan organik menjadi produk yang bermanfaat. Selain itu, dapat juga digunakan untuk mengontrol peningkatan limbah. Proses ini dianggap paling efisien dan ramah lingkungan, karena kompos dapat digunakan sebagai kondisioner tanah yang mengandung nutrisi tinggi untuk tanah. Komunitas mikroba dalam kompos yang merupakan bakteri, jamur dan cacing juga dapat menstabilkan bahan organik yang terdegradasi. Kinerja proses pengomposan juga akan tergantung pada karakteristik limbah karena pengomposan hanya cocok untuk limbah yang dapat terurai secara hayati (Gonawala and Hemali, 2018).

Prosedur pertama untuk membuat kompos adalah formulasi bahan baku. Maka $\mathrm{C} / \mathrm{N}$ rasio dari campuran harus di antara 30 - 35 untuk memastikan kondisi yang tepat bagi mikroorganisme untuk mengurai dan mengubah bahan organik (Sánchez et al, 2017).

Pupuk organik merupakan produk utama dari pengomposan. Pupuk organik meningkatkan kesuburan tanah, struktur tanah, kapasitas menahan air, sifat fisika dan kimia, pH tanah, aktivitas mikroba dan juga produksi tanaman (Muhammad and Khattak, 2009). Manfaat pupuk organik untuk tanah dapat dilihat pada Tabel 2

Tabel 2 Manfaat Pupuk Organik Untuk Tanah

\begin{tabular}{|c|c|}
\hline Aspek & Manfaat \\
\hline Fisika & $\begin{array}{l}\text { - Ukuran partikel yang kecil akan memberikan ruang bagi infiltrasi air } \\
\text { dan pertukaran udara } \\
\text { - Meningkatkan struktur tanah dalam menjaga keseimbangan fisika- } \\
\text { kimia-mikrobiologis di dalam tanah }\end{array}$ \\
\hline Kimia & $\begin{array}{l}\text { - Pengurangan pestisida dalam tanah dengan membentuk ikatan dengan } \\
\text { molekul organik kompos } \\
\text { - Meningkatkan kesuburan tanah dengan bahan organik }\end{array}$ \\
\hline Mikrobiologi & $\begin{array}{l}\text { - Memberikan pasokan mikroorganisme dalam pembentukan tanah dan } \\
\text { pergerakan unsur hara } \\
\text { - Mikroorganisme bermanfaat untuk mengendalikan patogen dalam } \\
\text { tanah }\end{array}$ \\
\hline
\end{tabular}

(Sumber: Compost supplementation with nutrients and microorganisms in composing process, 2017)

Standar pupuk organik yang baik bagi lingkungan diatur dalam Peraturan Menteri Pertanian No. 70 Tahun 2011 Tentang Pupuk Organik, Pupuk Hayati dan Pembenah Tanah.

\section{Hasil Penelitian Terdahulu}

Tabel 3 Hasil Penelitian Terdahulu

\begin{tabular}{|c|c|c|}
\hline Judul Paper, Tahun & Penulis & Hasil Penelitian \\
\hline $\begin{array}{l}\text { Effective Use of Cow } \\
\text { Dung Manure for Healthy } \\
\text { Plant Growth, } 2017\end{array}$ & Ram, Mangtu & $\begin{array}{l}\text { - Kotoran sapi memiliki 3\% Nitrogen, Fosfor } \\
\text { dan } 1 \% \text { Kalium } \\
\text { - Bakteri dalam kotoran sapi mengubah nutrisi } \\
\text { menjadi bentuk yang mudah diserap oleh } \\
\text { tanaman } \\
\text { - Kotoran sapi memiliki kadar air yang tinggi } \\
\text { sehingga memungkinkan aerasi yang baik }\end{array}$ \\
\hline $\begin{array}{l}\text { Efektivitas Proses } \\
\text { Pengomposan Sampah }\end{array}$ & $\begin{array}{l}\text { Widiyaningrum, Priyantini } \\
\text { dan Lisdiana }\end{array}$ & $\begin{array}{l}\text { - Pengomposan berlangsung dengan baik, } \\
\text { dibutuhkan bahan organik yang ideal serta }\end{array}$ \\
\hline
\end{tabular}




\begin{tabular}{|c|c|c|}
\hline Judul Paper, Tahun & Penulis & Hasil Penelitian \\
\hline $\begin{array}{l}\text { Daun Dengan Tiga } \\
\text { Sumber Aktivator } \\
\text { Berbeda, } 2015\end{array}$ & & $\begin{array}{l}\text { suhu lingkungan yang sesuai untuk } \\
\text { mikroorganisme } \\
\text { - Spesifikasi kompos dari sampah organik dan } \\
\text { sampah daun akan memenuhi standar apabila } \\
\text { kadar C/N rasio berkisar } 10-20 \text {, kadar air } \\
\text { maksimum } 50 \% \text { dan kisaran pH } 6.80-7.49 \\
\text { - Kualitas fisik kompos pada perlakuan ini } \\
\text { berwarna kehitaman, bau seperti tanah dan } \\
\text { bertekstur halus sesuai SNI 19-7030-2004 }\end{array}$ \\
\hline $\begin{array}{l}\text { Organic Waste in } \\
\text { Composting: A Brief } \\
\text { review, } 2018\end{array}$ & $\begin{array}{l}\text { Gonawala, Suhas S. and } \\
\text { Hemali Jardosh }\end{array}$ & $\begin{array}{l}\text { - Manfaat pengomposan: mengurangi ruang } \\
\text { TPA, mengurangi kontaminasi permukaan } \\
\text { dan air tanah, mengurangi emisi metana. } \\
\text { - Komposisi sampah organik dapat digunakan } \\
\text { sebagai nutrisi untuk tanaman, bahan } \\
\text { tambahan tanah dan untuk pengelolaan } \\
\text { lingkungan } \\
\text { - Faktor yang berkontribusi pada kualitas } \\
\text { kompos karena sebagai jenis limbah organik } \\
\text { memiliki konsentrasi nutrisi yang berbeda } \\
\text { yaitu Nitrogen, Fosfor dan Kalium (N,P,K) } \\
\text { yang merupakan energi makro umum yang } \\
\text { ada dalam pupuk }\end{array}$ \\
\hline
\end{tabular}

\section{PENUTUP}

Dapat disimpulkan pengolahan sampah peternakan dan pertanian menjadi pupuk organik dengan metode pengomposan bermanfaat untuk mengurangi limbah dan mengolah sampah menjadi produk yang bernilai. Limbah peternakan salah satunya kotoran dan urin sapi memiliki kandungan nutrisi nitrogen, fosfor dan kalium yang baik bagi tanah sedangkan limbah pertanian memiliki kandungan nutrisi yang baik untuk mikroba. Proses ini dianggap paling efisien dan ramah lingkungan, karena kompos dapat digunakan sebagai kondisioner tanah yang dapat meningkatkan kesuburan tanah, struktur tanah, kapasitas menahan air, sifat fisika dan kimia, $\mathrm{pH}$ tanah, aktivitas mikroba dan juga produksi tanaman.

\section{DAFTAR PUSTAKA}

Febriyantiningrum, Kuntum., N. Nurfitria., A. Rahmawati. 2018. Studi Potensi Limbah Sayuran Pasar Baru Tuban Sebagai Pupuk Organik Cair. Seminar Nasional Penelitian dan Pengembangan Masyarakat.

Gonawala, Suhas S, and H. Jardosh. 2018. Organic Waste in Composting: A brief review. International Journal of Current Engineering and Technology, Vol 8(1).

DOI: https://doi.org/10.14741/ijcet.v8i01.10884

Hakami, Bader A., and El-Sayed Sedek Abu Seif. 2015. Household Solid Waste Composition and Management in Jeddah City, Saudi Arabia: A Planning Model. International Research Journal of Environmental Sciences. Vol 4(1):1-10.

Kalpana P., Sai Bramari G., L. Anitha. 2011. Formulation Of Potential Vegetable Waste Compost in Association With Microorganisms and Spirulina platensis. Asian Journal of Plant Science and Research 1(3):49-57.

Muhammad, D., and R.A. Khattak. 2009. Growth and Nutrient Concentrations of Maize in Pressmud Treated Saline-Sodic Soils. Soil \& Environ 28(2):145-155.

Ram, Mangtu. 2017. Effective Use of Cow Dung Manure For Healthy Plant Growth. International Journal of Advanced Research and Development. Vol 2(5):218-221. 
Revani, Brigitta., P. Purwaningrum., D. Indrawati. 2016. Penerapan Konsep 3R Melalui Bank Sampah Dalam Menunjang Pengelolaan Sampah Di Kelurahan Rawajati, Jakarta Selatan. Indonesian Journal Of Urban and Environmental Technology. Vol 8(1).

DOI: http://dx.doi.org/10.25105/urbanenvirotech.v8i1.719

Sánchez, Ó.J., et al. 2017. Compost Supplementation With Nutrients And Microorganisms In Composting Process. Waste Management.

DOI: http://dx.doi.org/10.1016/j.wasman.2017.08.012

Suprapto S., 2010. Peranan Teknologi Dalam Upaya Meningkatkan Potensi Nilai Ekonomi Sampah Dalam Sistem Pengolahan Sampah Domestik Terpadu Di Indonesia. Indonesian Journal Of Urban and Environmental Technology. Vol 5(4).

DOI: http://dx.doi.org/10.25105/urbanenvirotech.v5i4.683

Widiyaningrum, Priyantini dan Lisdiana. 2015. Efektivitas Proses Pengomposan Sampah Daun Dengan Tiga Sumber Aktivator Berbeda. Jurnal Penerapan Teknologi dan Pembelajaran Vol. 13(2).

DOI: $\underline{10.15294 / \text { rekayasa.v13i2.5604 }}$

Zaman M. M., et al. 2017. Effect Of Cow Dung As Organic Manure On The Growth, Leaf Biomass Yield Of Stevia rebaudiana and Post Harvest Soil Fertility. Journal Of Bangladesh Agricultural University. Vol 15(2):206-211.

DOI: https://doi.org/10.3329/jbau.v15i2.35064 